\title{
Effects of a simulated heat wave on photophysiology and gene expression of high- and low-latitude populations of Zostera marina
}

\author{
Gidon Winters ${ }^{1, *}$, Peter Nelle $^{1}$, Birgit Fricke $^{1}$, Gisep Rauch$^{1}$, Thorsten B. H. Reusch ${ }^{1,2}$ \\ ${ }^{1}$ Institute for Evolution and Biodiversity, Westfälische Wilhelms-Universität, Hüfferstrasse 1, 48149 Münster, Germany \\ ${ }^{2}$ Leibniz-Institut of Marine Sciences, IFM-GEOMAR, Department of Marine Ecology-Evolutionary Ecology of Marine Fishes, \\ Office Building West, Düsternbrooker Weg 20, 24105 Kiel, Germany
}

\begin{abstract}
Climate models predict increases in frequency of summer heat waves. In Europe, such events have already caused declines in seagrass meadows, highlighting the importance of short-term responses of local communities to climate stress. Understanding the variability among populations along the European thermal gradient in response to heat waves is crucial for seagrass conservation and management. Using a mesocosm we compared effects of a simulated heat wave on the photophysiology of Zostera marina populations coming from low ( $43^{\circ} \mathrm{N}$, Adriatic Sea) and high latitudes $\left(56^{\circ} \mathrm{N}\right.$, North and Baltic Seas). Measurements before, during and up to $4 \mathrm{wk}$ after the heat wave included photophysiological parameters derived from light response curves generated by PAM fluorometry and gene expression using qRT-PCR. In all 3 populations, initial exposures to thermal stress were characterized by increases in dark adapted effective quantum yield $\left(Y_{0}\right)$, maximum electron transfer rate of PSII $\left(E_{\text {TR }}\right.$ max $)$ and slope of the light response curve $(\alpha)$, coinciding with upregulations of the gene superoxidase dismutase [Mn]. With continuation of the heat wave these initial effects disappeared, demonstrated by declines in $Y_{0}, \mathrm{ETR}_{\max }$ and $\alpha$ relative to controls. $Z$. marina from the Adriatic suffered from the simulated heat wave as much as its high-latitude counterparts. However, we also demonstrate slight photophysiological differences between the populations during the recovery phase, where performance of high-latitude populations continued declining even after water temperatures returned to control levels, while photochemical activity fully recovered in the Adriatic population. These results might draw the attention of future studies and seagrass conservation efforts.
\end{abstract}

KEY WORDS: Zostera marina - Global change · Heat wave - Thermal stress - Gene expression · Antioxidant $\cdot$ PAM fluorometry $\cdot$ Real time PCR

\section{INTRODUCTION}

Recent heat waves in Central Europe, such as the $3 \mathrm{wk}$ of record-breaking temperatures during the summer of 2003 (Schär \& Jendritzky 2004, Schär et al. 2004), have been associated with declines in Zostera marina (eelgrass) populations (Greve et al. 2003, Reusch et al. 2005). Z. marina is the most widespread marine angiosperm (seagrass) species in the northern hemisphere (den Hartog 1970). Experimental work has confirmed that the declines were indeed due to high water temperatures (Ehlers et al. 2008, Bergmann et al. 2010) or the associated water column anoxia periods (Greve et al. 2003, Pulido \& Borum 2010). Z. marina is considered an ecological engineering species (Jones et al. 1994), its loss results in complete devastation of the associated biological community and its ecological services, entailing severe socio-economic consequences (Wyllie-Echeverria \& Cox 1999).

Current climate models for northern Europe predict increases in the frequency of similar summer heat waves for the near future (2071 to 2100; Schär et al. 
2004). For those seagrass populations growing along the European thermal gradient, a better understanding of the intra-specific and inter-specific variability in response to thermal stress has important implications for the ecology and evolution of seagrasses, as well as for future conservation and management of seagrass based ecosystems (Rice \& Emery 2003).

Short term climatic events causing environmental extremes leave little time for seagrasses or macroalgae to shift ranges (reviewed by Reusch \& Wood 2007). This highlights the importance of short-term responses, such as adapting photosynthetic efficiencies or the regulation and expression of important stress related genes, e.g. chaperones and antioxidants. Photosynthesis is among the first processes to be affected by elevated temperatures (Sharkey 2005), with photosystem II (PSII) and its components shown to be particularly sensitive to thermal stress (Havaux 1993, Dutta et al. 2009). Thus, photophysiological measurements have become an important tool in studying thermal stress in plants in general (Larcher 1994) and in marine primary producers in particular (Masini \& Manning 1997, Ralph et al. 1998, Campbell et al. 2006).

In seagrasses, pulse amplitude modulated (PAM) fluorometry has been commonly used for studying the effects of environmental stressors on a suite of photophysiological parameters (Ralph et al. 1998, Campbell et al. 2006, Sharon et al. 2009). Using PAM fluorometry, Massa et al. (2009) correlated reductions in photosynthetic performance and survival of shoots following exposures to thermal stress. As a next step towards understanding the molecular genetic mechanisms of physiological performance, gene expression studies using real-time quantitative polymerase chain reaction (qRT-PCR; Heid et al. 1996), may provide information as to which metabolic pathways are affected by (thermal) stress and explain the variability in stress responses among populations/individuals. Potentially relevant genes include antioxidant enzymes (Desalvo et al. 2008, Reusch et al. 2008) that detoxify reactive oxygen species (ROS) at times of thermal stress (Bowler et al. 1992) such as superoxide dismutase (SOD), catalase (CAT), or ascorbate peroxidase (APX).

Zostera marina is very useful for studying thermal adaptation within species as populations grow in very different thermal environments, ranging from temperate (e.g. the Northern Atlantic Ocean and the Baltic Sea) to subtropical waters (e.g. Sea of Cortez or the Mediterranean; reviewed by Moore \& Short 2006). Comparing populations from locations with contrasting abiotic conditions can also be used as a proxy for future climatic changes (Etterson \& Shaw 2001). Provided that measurements are taken in a controlled environment (i.e. a common mesocosm setup), such comparisons could identify heritable differences in ecophysiological traits (Ackerly et al. 2000) that are likely to be important under a changing climate (Jump \& Penuelas 2005, Millien et al. 2006). Furthermore, such studies could identify populations that possess traits such as resistance to thermal stress and could help to focus conservation efforts on these populations for future restoration (Peat \& Fitter 1994) or their possible use as donor material for denuded areas (i.e. 'genetic rescue'). The objectives of our work were to characterize the effects of a simulated heat wave of predicted duration and amplitude on low and high-latitude Zostera marina populations and determine whether or not high-latitude populations have a lower tolerance to thermal stress.

\section{MATERIALS AND METHODS}

Collection sites. Subtidal Zostera marina vegetative shoots (with attached roots) were collected during April to May 2008 from Doverodde (Denmark, Limfjord: $56^{\circ} 43.070^{\prime} \mathrm{N}, 008^{\circ} 28.446^{\prime} \mathrm{E}$ ), Ebeltoft (Denmark, Baltic Sea: $56^{\circ} 12.499^{\prime} \mathrm{N}, 010^{\circ} 34.647^{\prime} \mathrm{E}$ ), and Gabicce Mare (Italy, Adriatic sea: $43^{\circ} 57.967^{\prime} \mathrm{N}, 012^{\circ} 45.859^{\prime} \mathrm{E}$ ) (Fig. 1), representing both high and low-latitude populations. Sampling was from 1.5 to $3 \mathrm{~m}$ depth and seawater temperatures at collection were from 12 to $16^{\circ} \mathrm{C}$. Long term surface water temperatures and salinities at sites were obtained from local metrological and marine monitoring services.

At each of the 3 sites, $\sim 15$ different spots $(\sim 50 \mathrm{~cm}$ in diameter, and $\geq 5 \mathrm{~m}$ apart from each other to minimize sampling identical clones) within the local seagrass meadow were sampled. From each spot $\sim 30$ leaf shoots (morphological 'individuals' = ramets; Procaccini et al. 2007) were collected. Shoots were transported submerged in seawater and planted into our mesocosm facility (located in Münster, Germany) within 30 h after uprooting.

Mesocosm facility. After collection, both high and low-latitude Zostera marina populations were grown together in an indoor mesocosm facility (Fig. 2). This facility included 2 plastic storage tanks (for warm and for cold seawater, $173 \times 110 \times 97 \mathrm{~cm}$ each), connected to 12 smaller $(120 \times 100 \times 87 \mathrm{~cm})$ plastic tanks that could be independently connected to either warm or cold water circuits. Tanks were filled with reverseosmosis water adjusted to a salinity of 31 psu using artificial sea salt (Instant Ocean, USA; $700 \mathrm{l}$ in each of the 12 small tanks, $930 \mathrm{l}$ in each storage tank). Salinity was monitored daily (WTW LF197 conductivity meter) and kept at this level by adding deionized water as appropriate. Water was pumped through this system at $1200 \mathrm{l} \mathrm{h}^{-1}$. To ensure similar water chemistry between cold and warm circuits, water was 

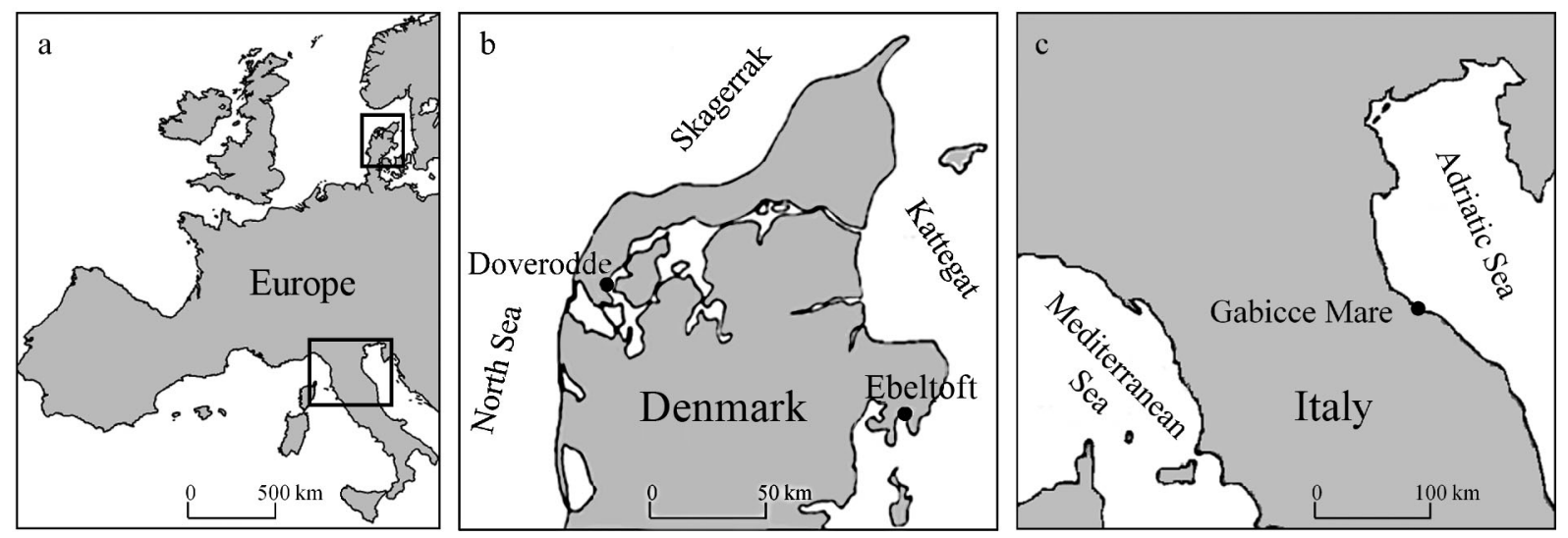

Fig. 1. Zostera marina. (a) Overview of collection sites. (b) High-latitude sites: Doverodde (North Sea, Denmark) and Ebeltoft (Baltic Sea, Denmark). (c) Low-latitude site: Gabicce Mare (Adriatic Sea, Italy)

allowed to pass between the 2 storage tanks at a rate of $1200 \mathrm{l} \mathrm{h}^{-1}$. While this experimental system was closed, we replaced $8 \%$ of the total water content of the mesocosm with fresh 31 psu seawater every 7 to 10 d. Within each circuit, water was mechanically filtered (Sta-Rite Posi-Flo II PTM70 cartridge filter; Sta-Rite), ozonized (S1000 Ozonizer, 8206 redox transmitter; Bürkert), and protein skimmed ('Fresh skim' model; Sander Aquarientechnik). Light was provided by 2 different metal halide lamps optimized for plant spectrum (Master Green Power T $2000 \mathrm{~K}$ and Master HPI-T PLUS $4000 \mathrm{~K}_{\text {; }}$ Philips) hung $50 \mathrm{~cm}$ above each tank. Light intensity in the spectral range from 400 to $700 \mathrm{~nm}$ was measured with a QSO-E micro quantum sensor (Apogee Instruments) connected to a Mastech voltmeter (calibrated against a Li-190 quantum sen-

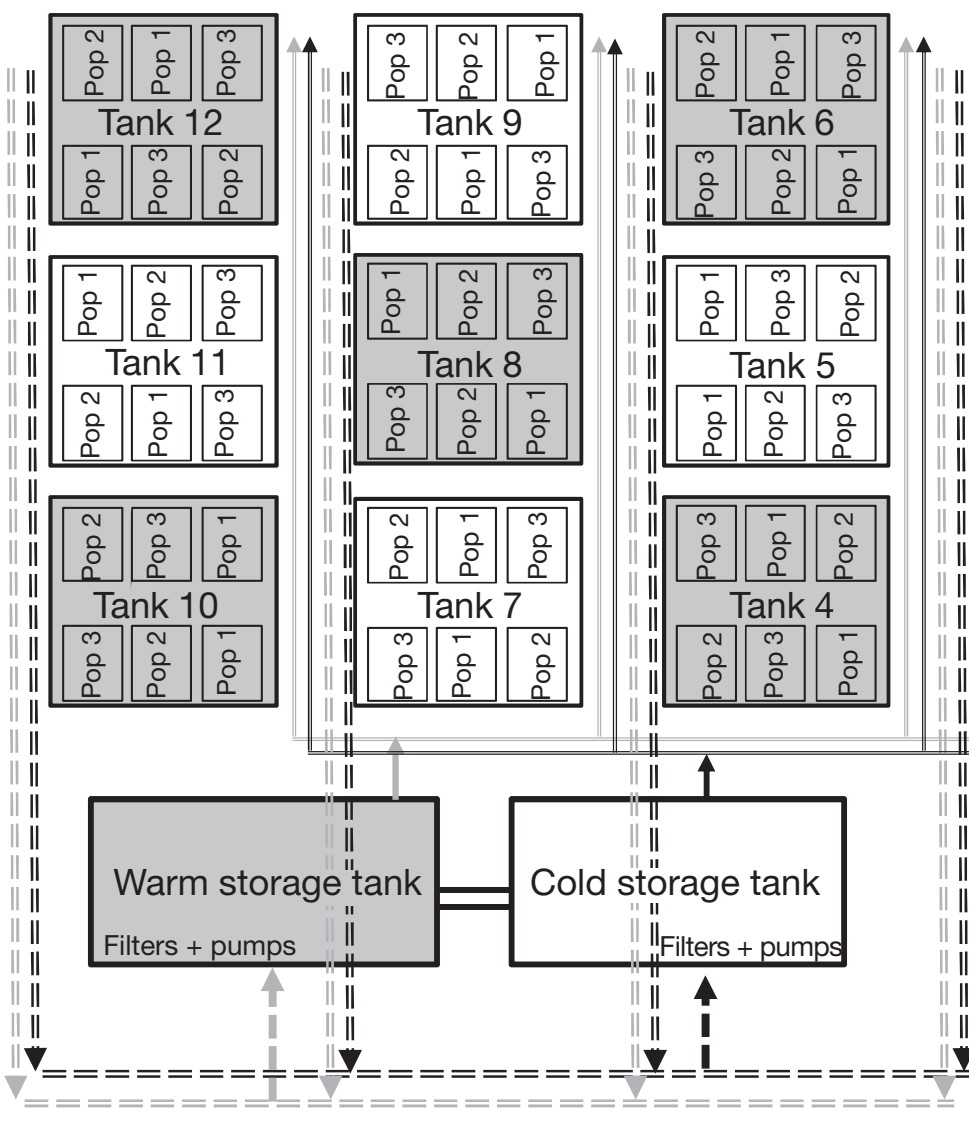

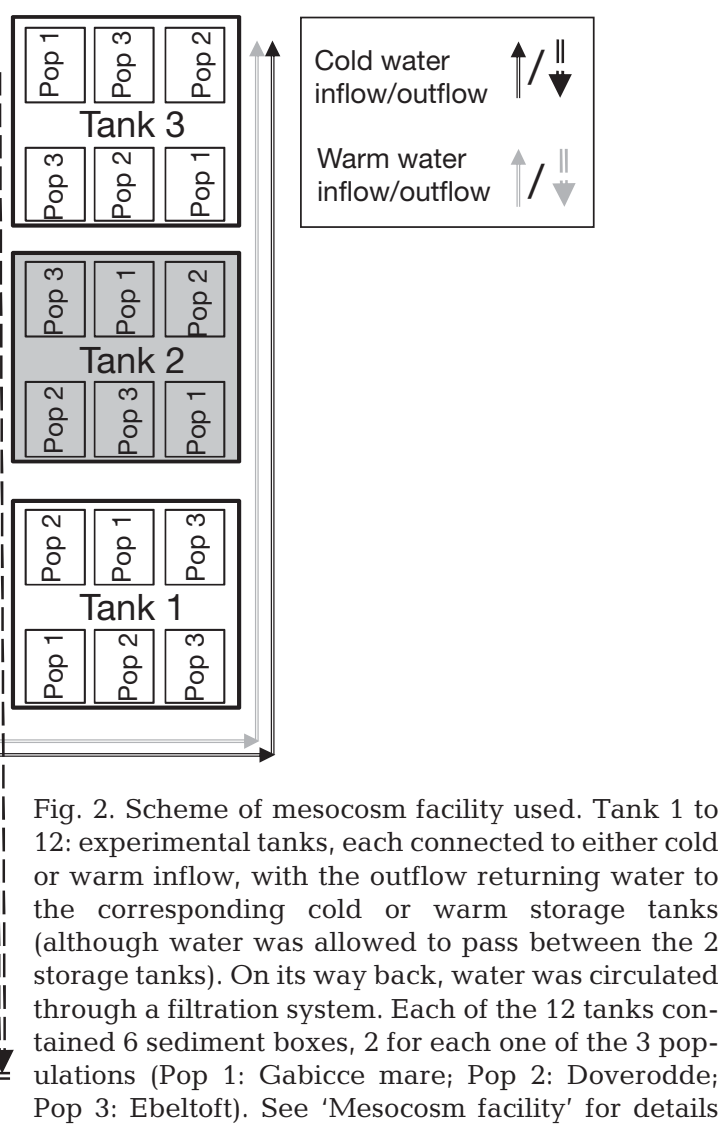


sor). Intensities ranged from 900 (just under the water surface of the tanks) to $300 \mu \mathrm{mol} \mathrm{m} \mathrm{m}^{-2} \mathrm{~s}^{-1}$ (sediment surface of the boxes). Each of the 12 experimental tanks $(6 \times$ thermal stress, $6 \times$ control), housed 6 plastic boxes ('sediment boxes', $36.5 \times 26.5 \times 10 \mathrm{~cm}$ each), 2 boxes per each of the 3 populations, i.e. a total of 72 sediment boxes spread out in 12 tanks (Fig. 2). Sediment boxes were filled to a height of $10 \mathrm{~cm}$ with natural sediment from the south western Baltic Sea. Preliminary work found that growth rates were not affected by different marine or beach sediment combinations (see supplementary materials in Bergmann et al. 2010).

Within each sediment box we planted 9 to 15 shoots of only 1 population that originated from 7 different sampling spots within this population's original meadow (in total 294, 235 and 330 vegetative shoots from Ebeltoft, Doverodde and Gabicce Mare, respectively). This planting regime was used to control for genotypic diversity within boxes. Importance of seagrass genotypic diversity in resilience to thermal stress has been previously demonstrated (Reusch et al. 2005, Ehlers et al. 2008). Shoots originating from the same spot within a meadow were assumed to be ramets belonging to the same genet (Procaccini et al. 2007) and were marked with cable ties and colored rings. Thus, for each box it was assumed that the 12 to 15 shoots represented at least 7 different genotypes. Once in the mesocosm, samples were taken for genotyping from all populations to confirm the existence of similar genotypic diversities between the collected populations (see Bergmann et al. 2010).

Following planting, salinity and water temperature (26 psu and $14^{\circ} \mathrm{C}$ at time of planting) were gradually increased $\left(1 \mathrm{psu} \mathrm{d}^{-1}, 0.5^{\circ} \mathrm{C} \mathrm{d}^{-1}\right.$; these temperature increments resemble late spring field conditions), up to the starting levels chosen for our experiment (31 psu, $19^{\circ} \mathrm{C}$ ), after which all shoots were given another $21 \mathrm{~d}$ to acclimate to the mesocosm conditions (before T0). Although this stage involved a short exposure of Adriatic plants to salinities lower than levels at the collection sites, growth rates monitored during this stage indicated no signs of stress. Shoots were provided with a 16:8 $\mathrm{h}$ light:dark cycle to mimic day length in the Baltic area during collection time. During the experiment proper (see 'Heat wave simulation'), daily light: dark cycles were adjusted over time to fit the natural light conditions (from 16:8 h light:dark in late May, to a 14:10 h in late August). Water was fertilized every $10 \mathrm{~d}$ (final concentrations in the mesocosm of $15 \mu \mathrm{mol} \mathrm{l^{-1 }}$ $\mathrm{NaNO}_{3}, 1 \mu \mathrm{mol} \mathrm{l} \mathrm{l}^{-1} \mathrm{NaH}_{2} \mathrm{PO}_{4}-\mathrm{H}_{2} \mathrm{O}$ and $6 \mu \mathrm{mol} \mathrm{l} \mathrm{l}^{-1}$ $\mathrm{Na}_{2} \mathrm{SiO}_{4}-9 \mathrm{H}_{2} \mathrm{O}$, mimicking spring nutrient conditions). After the heat wave itself, fertilization was stopped to simulate the Baltic Sea's low nutrient levels in late summer.
Heat wave simulation. Following $21 \mathrm{~d}$ of acclimation at a moderate summer temperature of $19^{\circ} \mathrm{C}$, the temperature in the heat stress treatment tanks was slowly increased from $19^{\circ} \mathrm{C}$ (June 4) to $25^{\circ} \mathrm{C}$ (June 9) at $1^{\circ} \mathrm{C}$ $\mathrm{d}^{-1}$ (see Fig. 4a). The temperature of $25^{\circ} \mathrm{C}$ was kept for $3 \mathrm{wk}$ to simulate a summer heat wave situation in the field (e.g. the 2003 European heat wave). Then (starting July 1), water temperature in the heat stress tanks was returned from $25^{\circ} \mathrm{C}$ back to $19^{\circ} \mathrm{C}\left(1.0\right.$ to $1.5^{\circ} \mathrm{C} \mathrm{d}^{-1}$ over $7 \mathrm{~d}$ ) and kept for another $4 \mathrm{wk}$ till the end of the experiment. The control treatment was kept at $19 \pm$ $1^{\circ} \mathrm{C}$ throughout the experiment. Water temperatures within 2 control and 2 experimental tanks were measured every 1 min using PT-100 thermistors $\left( \pm 0.1^{\circ} \mathrm{C}\right.$; Bohn Elektronik) connected to a desktop PC data logger system (PCI Base II analogue card, MAD16F module; BMC). Water temperatures are presented as daily mean values.

Fluorescence measurements. Photophysiological effects of the heat wave treatment were assessed by rapid light response curves (RLCs) generated by the PAM-2000 chlorophyll fluorometer (Walz). RLCs were performed 6 to $8 \mathrm{~h}$ after lights were switched on using the dark leaf clip attached to the leaf measured. RLCs were started $10 \mathrm{~s}$ after the dark leaf clip was in place (Ralph \& Gademann 2005). The first quantum yield measurement in this routine was performed in the absence of actinic light (i.e. $10 \mathrm{~s}$ dark-adapted effective quantum yield, $Y_{0}$; Saroussi \& Beer 2007), after which the actinic light was switched on and incremented in 9 pre-calibrated steps $(11,60,100,170,270,420,600$, 970 and $1410 \mu \mathrm{mol}$ photons $\mathrm{m}^{-2} \mathrm{~s}^{-1}$ ). Each step lasted $10 \mathrm{~s}$ and was followed by a measurement of the effective quantum yield $\left(\Delta F / F_{\mathrm{m}}{ }^{\prime}\right)$ after which light was increased to the next irradiance level (Ralph \& Gademann 2005).

All PAM measurements were taken underwater on the base of the 2 nd youngest leaf ( $n=6$ randomly chosen shoots at each time point), after removal of epiphytes. This position was chosen since it represents similar distances from the surface (and thus from the light source) among plants with different leaf lengths. Irradiance levels at this position ranged between 350 to $400 \mu \mathrm{mol}$ photons $\mathrm{m}^{-2} \mathrm{~s}^{-1}$ (measured with the micro quantum sensor setup mentioned above). The leaf's absorption factor (AF) was calculated by measuring the downwelling ambient PAR above and below the horizontally placed leaf (Beer \& Björk 2000). For this, the micro quantum sensor was placed on and below the same part of the 2nd youngest leaf to be measured with the PAM assuming that all light was absorbed by the leaves' photosynthetic pigments (Saroussi \& Beer 2007). $\Delta F / F_{\mathrm{m}}{ }^{\prime}$ values from each step were multiplied by the appropriate PAR value of that step, 0.5 (assuming that both photosystems absorbed equal amounts of 
incoming photons; Beer \& Björk 2000) and the AF, resulting in the electron transfer rate $(E T R, \mu m o l$ electrons $\mathrm{m}^{-2} \mathrm{~s}^{-1}$ ). ETR values were plotted against the incident absorbed PAR (Ia = incident PAR $\times$ AF; Saroussi \& Beer 2007). The non-linear least-squares regression model of Eilers \& Peeters (1988) was used to fit ETR-Ia curves and estimate the slope of the linear phase of the light response curve $(\alpha)$ and the maximum electron transfer rate $\left(\mathrm{ETR}_{\max }\right)$.

In order to facilitate the visualization of results, chlorophyll fluorescence parameters $\left(Y_{0}, \alpha\right.$ and ETR $\left._{\max }\right)$ measured for plants in the heat wave treatment were normalized to their appropriate controls (from the same population measured at the same time), i.e. we show means of relative (warm/control) values (Desalvo et al. 2010) with propagated SEs calculated using an error propagation calculator (http://laffers.net/tools/ error-propagation-calculator.php; accessed 15 May 2010). For the statistical analysis of the chlorophyll fluorescence parameters, measured values (i.e. none relative) were used.

RNA extraction and preparations of cDNA. RNA extractions and preparations of cDNA are detailed in Bergmann et al. (2010). Briefly, for RNA extraction, 12 leaf samples from each population and treatment were collected at time points T1 to T5 and T9, cleaned from epiphytes and blotted dry using tissue paper. Samples were inserted into plastic tubes containing a steel ball, immediately dipped into liquid nitrogen and kept on ice. Leaves were homogenized and thereafter taken for the first step in the RNA extraction using Invisorb RNA Plant HTS 96 Kits (Invitek). RNA was reverse transcribed using the Omniscript RT kit (Qiagen) and the resulting cDNA was diluted 1:50 prior to qRT-PCR assays.
Gene identification and primer design. Genes of interest were identified using the 'Data repository for Zostera marina and Posidonia oceanica ESTs' (http://drzompo.uni-muenster.de/search/searchform; accessed during 1 May to 15 September 2008) (Wissler et al. 2009). Search words included 'photosystem', 'oxidative stress' and 'antioxidant'. Target sequences were aligned with putatively homologous sequences from both Arabidopsis thaliana and Oryza sativa, taking advantage of their well annotated genomes (The Arabidopsis Information Resource, TAIR, and the Rice Genome Annotation Project, RGAP).

Primers (Table 1) were designed using Primer3 (Rozen \& Skaletsky 2000). Selection conditions included: product size (110 to $130 \mathrm{bp}), T_{\mathrm{M}}\left(57\right.$ to $\left.60^{\circ} \mathrm{C}\right)$ and GC content (40 to $60 \%$ ); these conditions facilitated cross-comparison of assays and assured similar PCR efficiencies (Ransbotyn \& Reusch 2006). At least one of the primers was placed across an exon-exon boundary to avoid genomic amplification. Exon-exon boundaries were located manually using BioEdit (v7.0.9; Hall 1999) through the gene models and locus details provided by TAIR and RGAP. Sequence alignments of the homologous sequences from both Arabidopsis thaliana and Oryza sativa together with that of Zostera marina were performed with CLUSTALW (EMBL-EBI) embedded in BioEdit. Only BLAST hits with $\mathrm{p}<0.001$ were considered.

Quantitative real-time PCR (qRT-PCR). $q R T-P C R$ was performed on an ABI PRISM 7000 instrument (Applied Biosystems) using the SYBR Green QPCR Master Mix (ABgene). Baseline and cycle threshold $\left(C_{\mathrm{T}}\right)$ were set manually for each gene and kept consistent among different assays. Expression levels of all genes were normalized to the 'house keeping' gene

Table 1. Primer pairs used in Zostera marina quantitative real-time PCR assays. F: forward; R: reverse

\begin{tabular}{|c|c|c|c|}
\hline Gene name & Symbol & Function & Primer sequence \\
\hline Eukaryotic initiation factor $4 \mathrm{~A}$ & eIF4A & $\begin{array}{l}\text { Translation initiation factor } \\
\text { (house keeping gene) }\end{array}$ & $\begin{array}{l}\text { F 5'-TCTTTCTGCGATGCGAACAG-3' } \\
\text { R 5'-TGGATGTATCGGCAGAAACG-3' }\end{array}$ \\
\hline Glutathione S-transferase & GST & Chemical defense & $\begin{array}{l}\text { F 5'-CATGAATCCATTCGGACAAG-3' } \\
\text { R 5'-CAGCAAGGTGAGTAAGGTCAG-3' }\end{array}$ \\
\hline Ascorbate peroxidase & APX & Antioxidant & $\begin{array}{l}\text { F 5'-GGTGATTTCTACCAGCTTGC-3' } \\
\text { R 5'-GATCCGCACCTTGGGTA-3' }\end{array}$ \\
\hline Superoxidase dismutase [Mn] & SOD & Antioxidant & $\begin{array}{l}\text { F 5'-ATGGGTGTGGCTTGCTTA-3' } \\
\text { R 5'-ATGCATGCTCCCATACATCT-3' }\end{array}$ \\
\hline Catalase & CAT & Antioxidant & $\begin{array}{l}\text { F 5'-ACAAAATTCCGTCCGTCA-3' } \\
\text { R 5'-GTCCTCAAGGAGTATTGGTCCTC-3' }\end{array}$ \\
\hline $\begin{array}{l}\text { Photosystem I, } \\
\text { reaction center subunit IV }\end{array}$ & PS I & $\begin{array}{l}\text { Photosynthesis, } \\
\text { chloroplast precursor }\end{array}$ & $\begin{array}{l}\text { F 5'-GGGAACCAAGGTGAAGATT-3' } \\
\text { R 5'-GAATCTCACCACAACTGGGTA-3' }\end{array}$ \\
\hline $\begin{array}{l}\text { Photosystem II, } \\
22 \text { kDa protein }\end{array}$ & PS II & $\begin{array}{l}\text { Photosynthesis, } \\
\text { chloroplast precursor }\end{array}$ & $\begin{array}{l}\text { F 5'-TTCCCAAAAAGGTGGTAGTTA-3' } \\
\text { R 5'-ATAAAGAAGCGGCAAAACC-3' }\end{array}$ \\
\hline
\end{tabular}


(HKG; Pfaffl et al. 2002) eIF4A (Table 1), shown to be consistent in seagrass tissue exposed to thermal stress (Ransbotyn \& Reusch 2006).

Reactions were run in duplicates using 5 biological replicates (for each time point, population and treatment; samples chosen randomly out of 12 RNA extractions). A triplicate plate was run only when the technical variation (varT), calculated as the mean of the variation in housekeeping gene expression (varT = $0.15)$ was $>0.45$ (= $0.3+\operatorname{varT})$. Reactions $(15 \mu \mathrm{l})$ included $8 \mu \mathrm{l} \mathrm{SYBR}$ Green PCR Master Mix, $100 \mathrm{nM}$ forward and reverse primers and $2 \mu$ diluted (1:50) cDNA template. Thermocycling conditions included: $15 \mathrm{~min}$ hot start at $95^{\circ} \mathrm{C}, 40$ cycles of $15 \mathrm{~s}$ at $95^{\circ} \mathrm{C}$, and $1 \mathrm{~min}$ at $60^{\circ} \mathrm{C}$. To verify that the reaction yielded only a single product, a dissociation protocol $\left(15 \mathrm{~s}\right.$ at $95^{\circ} \mathrm{C}$, $20 \mathrm{~s}$ at $60^{\circ} \mathrm{C}$ and $15 \mathrm{~s}$ at $95^{\circ} \mathrm{C}$ ) followed the above thermocycling profile.

Initial work included screening potential genes of interest, confirmation of desired amplicons, ensuring that only cDNA was amplified and running 1:10 to 1:640 dilution curves for the HKG and target genes. PCR efficiencies $(E)$ were calculated as $E=10^{-1 / \text { slope }}-1$, with all $E>0.91$, and all $\mathrm{R}^{2}>0.95$.

Relative messenger RNA (mRNA) transcription levels were based on the $\Delta \Delta \mathrm{Ct}$ method (Livak \& Schmittgen 2001) using the REST-MCS software (Pfaffl et al. 2002), wherein $E$ and $C_{\mathrm{T}}$ values for each primer set, biological sample $(n=5)$, treatment and time point were used to calculate $\Delta \Delta C_{\mathrm{T}}$. Relative expression $\left(2^{-\Delta \Delta C \mathrm{~T}}\right)$ was calculated by REST-MCS on a $\log 2$ scale.

Statistical analysis. The assumptions for normality of response variables $Y_{0}, \mathrm{ETR}_{\max }$ and $\alpha$ were examined graphically. Photophysiological data were analyzed using STATISTICA 9.0 (Statsoft). For simplifying the analysis, separate 2-way ANOVAs were performed for different stages of the experiment, including before (T0) and during the heat wave (T2 to T4; data from these time points were pooled), post treatment (T5 to T6; data from these time points were pooled), and after a recovery period (T9). In each of these tests, we used a factorial 2-way ANOVA with 'Treatment' (control or simulated heat wave) and either 'Population' (Gabicce Mare, Doverodde, Ebeltoft) or 'Geographic origin' of the plants (high or low latitudes) treated as fixed (predicted) factors, with $Y_{0}, \mathrm{ETR}_{\max }$ or $\alpha$ as dependent variables. $Y_{0}$ data were arc sin transformed before this analysis (this transformation is appropriate for proportional observations, e.g. $Y_{0}$; Fowler et al. 1998).

For the gene expression data, within each time point, differences in the transcript levels of mRNA between control and heat wave treatment were assessed using randomization tests implemented within the RESTMCS software (Pfaffl et al. 2002) with differences considered significant at $\mathrm{p}<0.05$.

\section{RESULTS}

\section{In situ water temperature}

Comparison of temperature data from the 3 sites showed that Adriatic populations of Zostera marina were exposed to summer water temperatures $>6^{\circ} \mathrm{C}$ warmer than for their higher-latitudes conspecifics (Fig. 3). Summer (June to August) water temperatures (mean $\pm \mathrm{SD}$ ) in Gabicce Mare were $24.5 \pm 0.25^{\circ} \mathrm{C}$ (2003 to 2008; Fig. 3c), compared with $18.4 \pm 0.01^{\circ} \mathrm{C}$ in the Limfjord (near Doverodde; 2003 to 2008; Fig. 3b) and $17.0 \pm 0.15^{\circ} \mathrm{C}$ (near Ebeltoft; 2004 to 2008; Fig. 3a). Temperature data showed Z. marina from Gabicce Mare had been exposed to thermal stress events in recent years $(2003,2006)$, when maximum water temperatures reached 28.4 or $27.8^{\circ} \mathrm{C}$, respectively. In comparison, warm summers caused maximum water temperatures of $22.45^{\circ} \mathrm{C}$ in Doverodde $(2003,2006)$ and $22.55^{\circ} \mathrm{C}$ near Ebeltoft $(2004$, 2006). We thus assume that exposing $Z$. marina from Gabicce Mare to the mesocosm's heat wave $\left(\sim 25^{\circ} \mathrm{C}\right.$ for $3 \mathrm{wk}$ ) was equivalent to a moderate summer, 2 to $3^{\circ} \mathrm{C}$ less than temperatures measured during recent natural heat waves. However, exposing the high-latitude populations to the mesocosm heat wave represented a very extreme situation at present but a likely scenario for the coming future (2071 to 2100; Schär et al. 2004).

At Gabicce Mare, salinities (means $\pm \mathrm{SD}$ ) ranged between 20.9 and 38.1 psu for 2003 to 2008 (34.21 \pm 0.19 psu). In April-May, when we collected the seagrass, mean salinity was 34.4 psu (Fig. 3c). Near Doverodde, salinity ranged between 21.4 and 32.8 psu for 2003 to 2008 (27.8 $\pm 0.2 \mathrm{psu}_{\text {; }}$ for April to May: $27 \pm 0.4 \mathrm{psu}_{i}$ Fig. 3b). Near Ebeltoft, salinities ranged between 15 and $29.2 \mathrm{psu}$ for 2003 to 2006 (21.5 $0.2 \mathrm{psu}$; for April to May: $20.3 \pm 0.5$ psu; Fig. 3a).

\section{Mesocosm water temperatures}

Daily mean water temperatures in control tanks were kept at 18.9 to $20.0^{\circ} \mathrm{C}$ throughout the experiment. In the treatment tanks, temperatures were 24.9 to $26.7^{\circ} \mathrm{C}$ during the heat wave experiment (T2 to T4) and 18.6 to $19.1^{\circ} \mathrm{C}$ after the return to control temperatures (T5 to T9). Towards the end of the experiment, we had 2 minor temporary failures in our mesocosm cooling system (a 'second heat wave') causing daily mean water temperatures to rise to $21^{\circ} \mathrm{C}$ (July 29) and $20.5^{\circ} \mathrm{C}$ (August 2) in all tanks (Fig. 4a).

\section{Dark-adapted effective quantum yield $\left(Y_{0}\right), \alpha$ and ETR $_{\max }$}

Throughout the heat wave experiment (T2 to T4) $Y_{0}$ values were found to be significantly different from the control values (Tables $2 \& 3,2$-way ANOVA, $p<0.01$ ). In 

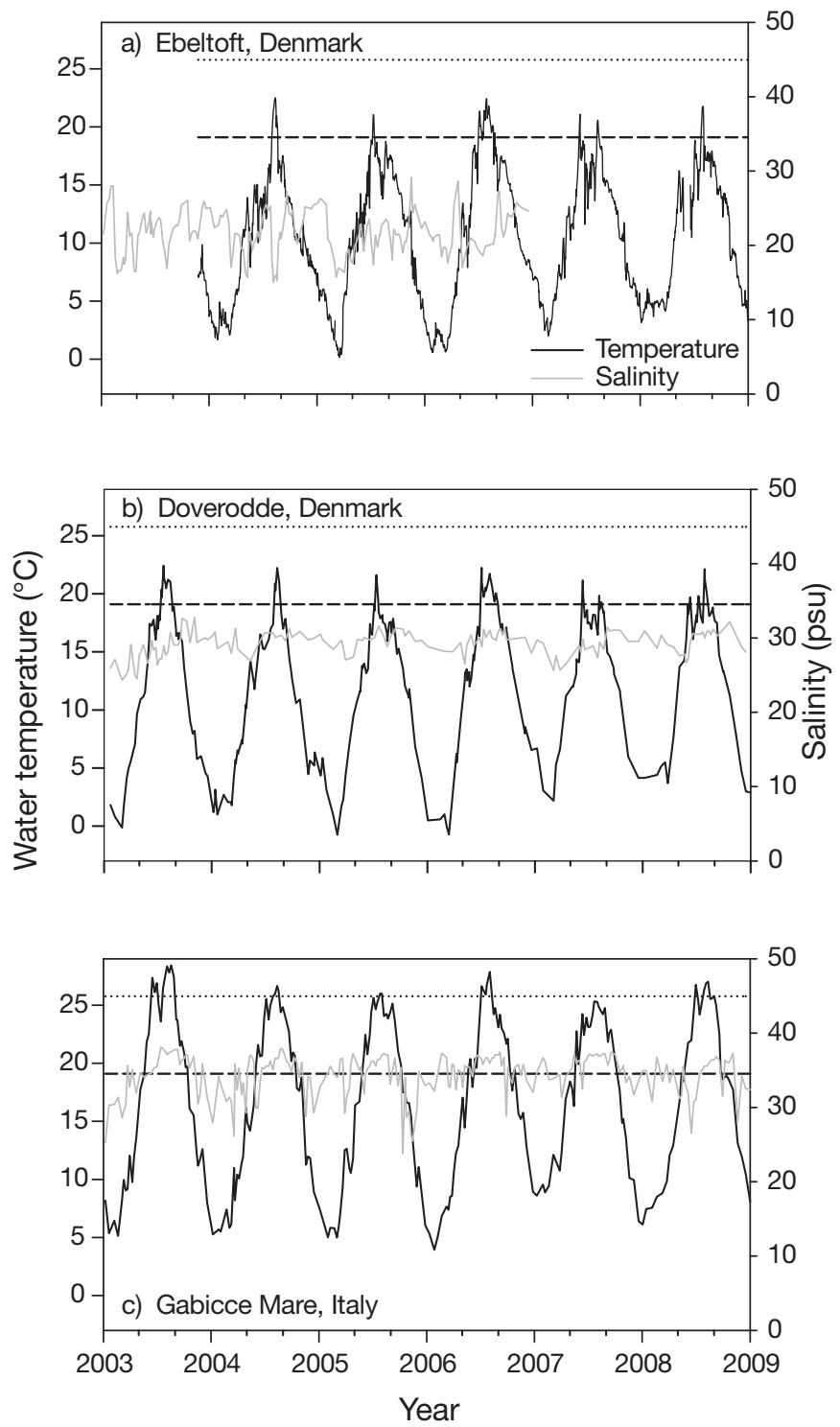

Fig. 3. In situ surface water temperatures (black line ${ }^{\circ} \mathrm{C}$ ) and salinities (grey line psu) as recorded near the 3 collection sites. (a) Ebeltoft, Denmark. Daily average surface water temperatures measured at Stn 22331, 56 $09^{\prime} \mathrm{N}, 10^{\circ} 13^{\prime} \mathrm{E}$. Source: Danish Meteorological Institute (DMI). Surface salinities measured every 7 to $10 \mathrm{~d}$ at $\mathrm{Stn} 170006,56^{\circ} 09^{\prime} \mathrm{N}$, $10^{\circ} 19^{\prime}$ E. Source: The Danish national database for marine data (MADS); National Environmental Research Institute (NERI), Aarhus University, Denmark. (b) Doverodde, Denmark. Surface water temperatures and salinities measured every 7 to $14 \mathrm{~d}$, and averaged over 3 stations near Doverodde: VIB3721 (56 $\left.41.870^{\prime} \mathrm{N}, 08^{\circ} 35.610^{\prime} \mathrm{E}\right), \mathrm{VIB} 3722$ $\left(56^{\circ} 46.370^{\prime} \mathrm{N}, \quad 08^{\circ} 30.750^{\prime} \mathrm{E}\right)$, and VIB3705 (56 $39.400^{\prime} \mathrm{N}$, $08^{\circ} 42.380^{\prime}$ E). Source: Agency for Spatial and Environmental Planning, Ministry of the Environment, Denmark. (c) Gabicce Mare, Italy. Surface water temperatures and salini-

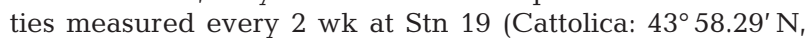
$12^{\circ} 44.46^{\prime}$ E). Source: Agenzia Regionale per la Prevenzione e l'Ambiente dell'Emilia-Romagna (ARPA). Also shown in each panel: temperature ranges $\left({ }^{\circ} \mathrm{C}\right)$ measured in our mesocosm facility during the simulated heat wave for the control $(---)$ and treatment (.......)
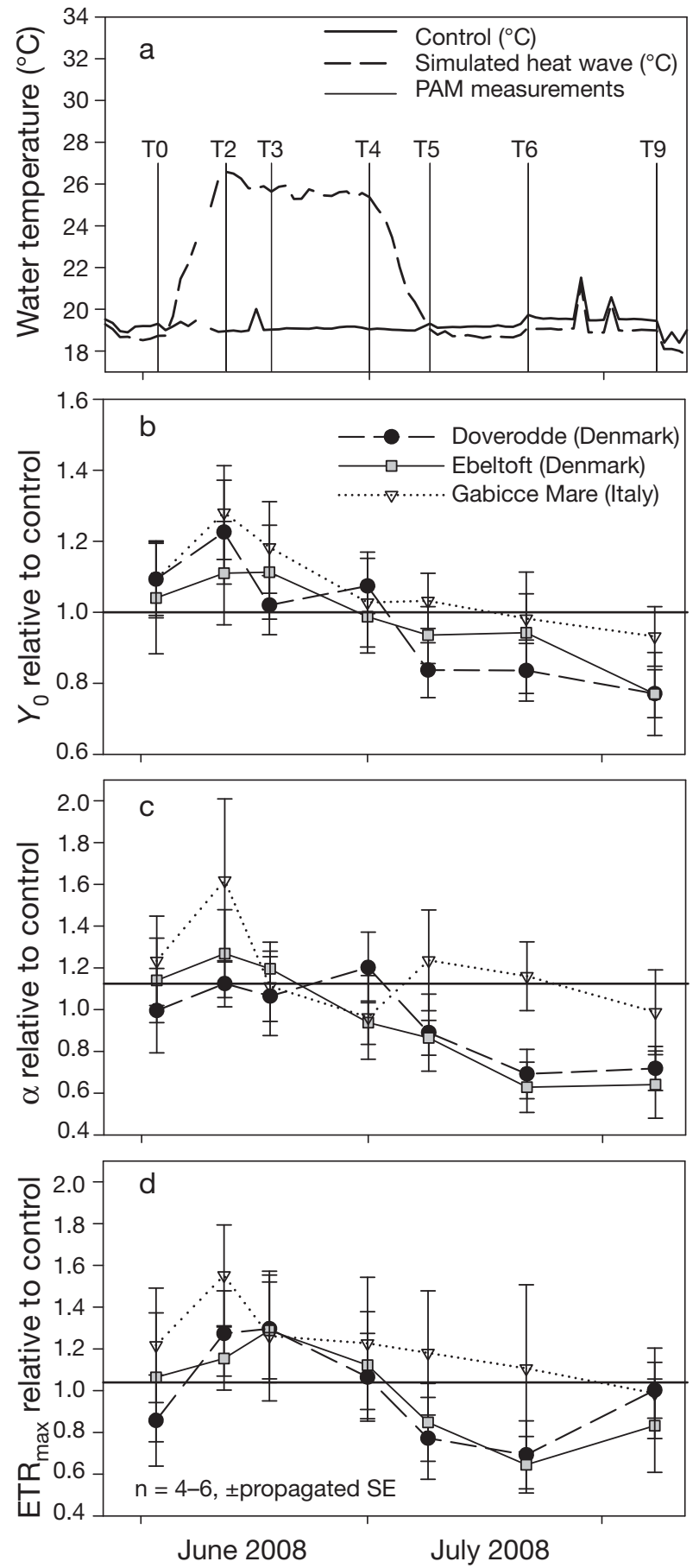

Fig. 4. Zostera marina. Effects of a 3 wk simulated heat wave on parameters derived from rapid light curves (RLCs) performed using 10 steps of incrementing light intensities (from 0 to $1140 \mu \mathrm{mol}$ photons $\mathrm{m}^{-2} \mathrm{~s}^{-1}$ ) on 3 populations of $Z$. marina. (a) Daily mean water temperature $\left({ }^{\circ} \mathrm{C}\right)$ in control and simulated heat wave tanks. (b) $Y_{0}$ (c) $\alpha$ and (d) ETR max $_{\text {mative to }}$ the control and measured over time for plants from Doverodde, Ebeltoft and Gabicce Mare exposed to control and simulated heat wave treatments. For each population and time point: means \pm propagated $\mathrm{SE}, \mathrm{n}=4$ to 6 . Values relative to the control were used to improve graphic clarity, yet the statistical analysis was done with the raw data 
Table 2. Factorial 2-way ANOVA tests assessing the effects of Treatment and Population (predictors), before (T0), during (T2 to T4), after the experimental heat wave (T5 to T6) and after a recovery period (T9) on $Y_{0}, \alpha$ or ETR max (dependent variables). ${ }^{*} \mathrm{p}<0.05,{ }^{* *} \mathrm{p}<0.01,-:$ not significant

\begin{tabular}{|c|c|c|c|c|c|c|c|c|c|}
\hline \multirow{2}{*}{$\begin{array}{l}\text { Time points } \\
\text { (experiment stages) }\end{array}$} & \multicolumn{3}{|c|}{ Treatment } & \multicolumn{3}{|c|}{ Population } & \multicolumn{3}{|c|}{ Treatment $\times$ Population } \\
\hline & $F$ & df & $\mathrm{p}$ & $F$ & $\mathrm{df}$ & $\mathrm{p}$ & $F$ & df & $\mathrm{p}$ \\
\hline \multicolumn{10}{|l|}{$Y_{0}$} \\
\hline T0 (before) & 1.276 & 1,29 & - & 2.509 & 2,29 & - & 0.097 & 2,29 & - \\
\hline T2-T4 (during) & 8.926 & 1,10 & ** & 0.443 & 2,10 & - & 0.415 & 2,10 & - \\
\hline T5-T6 (post treatment) & 3.621 & 1,63 & 0.061 & 1.556 & 2,63 & - & 1.768 & 2,63 & - \\
\hline T9 (recovery) & 0.561 & 1,30 & ${ }^{* *}$ & 0.654 & 2,30 & - & 1.044 & 2,30 & - \\
\hline \multicolumn{10}{|l|}{$\alpha$} \\
\hline T0 (before) & 1.113 & 1,27 & - & 0.060 & 2,27 & - & 0.367 & 2,27 & - \\
\hline T2-T4 (during) & 6.981 & 1,93 & $* *$ & 2.581 & 2,93 & - & 0.012 & 2,93 & - \\
\hline T5-T6 (post treatment) & 3.078 & 1,60 & - & 1.732 & 2,60 & - & 4.741 & 2,60 & * \\
\hline T9 (recovery) & 5.427 & 1,29 & * & 0.61 & 2,29 & - & 1.408 & 2,29 & - \\
\hline \multicolumn{10}{|l|}{ ETR $_{\text {max }}$} \\
\hline T0 (before) & 0.053 & 1,27 & - & 0.297 & 2,27 & - & 0.4431 & 2,27 & - \\
\hline T2-T4 (during) & 9.49 & 1,93 & $* *$ & 2.18 & 2,93 & - & 0.118 & 2,93 & - \\
\hline T5-T6 (post treatment) & 1.747 & 1,60 & - & 1.557 & 2,60 & - & 1.2405 & 2,60 & - \\
\hline T9 (recovery) & 0.254 & 1,29 & - & 1.076 & 2,29 & - & 0.1996 & 2,29 & \\
\hline
\end{tabular}

Table 3. Factorial 2-way ANOVA tests assessing the effects of Treatment and Geographic origin (predictors), before (T0), during

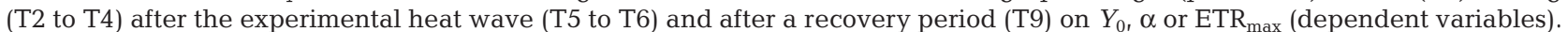
${ }^{*} \mathrm{p}<0.05,{ }^{* *} \mathrm{p}<0.01,-$ : not significant

\begin{tabular}{|c|c|c|c|c|c|c|c|c|c|}
\hline \multirow[t]{2}{*}{$\begin{array}{l}\text { Time points } \\
\text { (experiment stages) }\end{array}$} & \multicolumn{3}{|c|}{ Treatment } & \multicolumn{3}{|c|}{ Geographic origin } & \multicolumn{3}{|c|}{$\begin{array}{c}\text { Treatment } \times \text { Geographic } \\
\text { origin }\end{array}$} \\
\hline & $F$ & df & $\mathrm{p}$ & $F$ & df & $\mathrm{p}$ & $F$ & $\mathrm{df}$ & $\mathrm{p}$ \\
\hline \multicolumn{10}{|l|}{$Y_{0}$} \\
\hline T0 (before) & 1.185 & 1,31 & - & 1.175 & 1,31 & - & 0.046 & 1,31 & - \\
\hline $\mathrm{T} 2-\mathrm{T} 4$ (during) & 9.579 & 1,10 & $* *$ & 0.503 & 1,10 & - & 0.625 & 1,10 & - \\
\hline T5-T6 (post treatment) & 1.640 & 1,65 & - & 2.248 & 1,65 & - & 2.048 & 1,65 & - \\
\hline T9 (recovery) & 6.942 & 1,32 & $*$ & 0.591 & 1,32 & - & 2.171 & 1,32 & - \\
\hline \multicolumn{10}{|l|}{$\alpha$} \\
\hline T0 (before) & 1.494 & 1,29 & - & 0.055 & 1,29 & - & 0.493 & 1,29 & - \\
\hline T2-T4 (during) & 6.579 & 1,95 & ${ }^{*}$ & 5.079 & 1,95 & * & 0.020 & 1,95 & - \\
\hline T5-T6 (post treatment) & 0.309 & 1,62 & - & 0.428 & 1,62 & - & 8.862 & 1,62 & ** \\
\hline T9 (recovery) & 2.743 & 1,31 & - & 0.019 & 1,31 & - & 2.404 & 1,31 & - \\
\hline \multicolumn{10}{|l|}{$\mathbf{E T R}_{\max }$} \\
\hline T0 (before) & 0.187 & 1,29 & - & 0.186 & 1,29 & - & 0.571 & 1,29 & - \\
\hline T2-T4 (during) & 0.957 & 1,95 & ** & 3.72 & 1,95 & 0.056 & 0.210 & 1,95 & - \\
\hline T5-T6 (post treatment) & 0.584 & 1,62 & - & 2.90 & 1,62 & - & 2.576 & 1,62 & - \\
\hline T9 (recovery) & 0.141 & 1,31 & - & 2.245 & 1,31 & _- & 0.067 & 1,31 & _- \\
\hline
\end{tabular}

all 3 populations, these differences were characterized by initial increases in $Y_{0}$ at the onset of the experimental heat wave (T2), followed by a reversal of these effects with the prolonged exposure to the heat wave (T3 and onwards) (Fig. 4b). In all 3 populations, effects of the heat wave treatment on $Y_{0}$ were found even after temperatures were returned back to control levels, indicated by the strong trend found post treatment (T5 to T6, 2-way ANOVA, $p=0.061$; Tables $2 \& 3$ ) and even more by the significant difference found even after the recovery period (T9, 2-way ANOVA, p < 0.05; Tables 2 \& 3). We found no significant interactions involving Population or
Geographic origin, indicating that $Y_{0}$ values of plants responded similarly to the thermal stress throughout the experiment regardless of origin (Tables $2 \& 3$ ). However, slight differences between the populations were found during the recovery phase. Upon returning to control temperatures (T5), the $Y_{0}$ of the Gabicce Mare population seemed to decrease slightly over time (T5-T9) but at the end of the experiment (T9) was still very similar to levels of the control. In comparison, following the end of the heat wave (T5), in both high-latitude populations, $Y_{0}$ suffered a much larger decline that did not recover throughout this long recovery period (Fig. 4b). 
Similarly, for all 3 populations, both $\alpha$ and ETR $\max$ were found to be significantly different from their control values throughout the heat wave itself (T2 to T4; Tables $2 \& 3$, 2-way ANOVA, p < 0.05). In all 3 populations, the initial exposure to higher temperatures (T2 to T3) resulted in increases of $\alpha$ (Fig. 4c) and $\mathrm{ETR}_{\max }$ (Fig. 4d) relative to their controls. This was especially evident for the Gabicce Mare population where at T2 (only $1 \mathrm{~d}$ after temperature had reached $26^{\circ} \mathrm{C}$ ) both $\alpha$ and $\mathrm{ETR}_{\max }$, increased by 33 and $38 \%$, respectively, relative to the control (Fig. 4c,d). For $\alpha$, prolonged treatment effects were still evident in all 3 populations even after recovery (T9; 2-way ANOVA, $\mathrm{p}<0.05)$. Although we did not find significant Treatment $\times$ Population/Geographic origin interactions for ETR $_{\max }$, the significant Population $\times$ Treatment/Geographic origin interactions found for $\alpha$ post treatment (T5 to T6, 2-way ANOVA, p < 0.05; Tables 2 \& 3), along with the strong trend found for the effect of Geographic origin on $\mathrm{ETR}_{\max }$ during the heat wave itself (T2 to T4, 2-way ANOVA, p =0.056; Table 3) might indicate small differences between the populations and geographic origins of the plants in terms of their initial responses to the thermal stress (T2) and their photophysiology capacity post treatment and recovery (T5 to T9). Indeed, in both high-latitude populations, the prolonged exposure to the heat wave (T3 and onwards) resulted in a strong reduction not only in relative $Y_{0}$ (Fig. 4b), but also in relative $\alpha$ (Fig. 4c) and $\mathrm{ETR}_{\max }$ (Fig. 4d). Whereas relative $\alpha$ and $\mathrm{ETR}_{\max }$ of plants from the Adriatic population exposed to the heat wave were found to undergo a very slight reduction over time and at T9 were very similar to their control counterparts (relative values of $\sim 1.0$ ). For $\mathrm{ETR}_{\max }$ the main differences between the 3 populations appeared to be originating from the rate of decline in relative $\mathrm{ETR}_{\max }$, which seemed to be slower in the Adriatic population compared to both high-latitude populations. Both high-latitude populations were characterized by a recovery in relative $\mathrm{ETR}_{\max }$ values that occurred between T6 and T9.

\section{Gene expression}

In all 3 populations, thermal stress resulted in a significant upregulation of the antioxidant gene superoxidase dismutase [Mn] (SOD Mn). In plants from Gabicce Mare and Doverodde, this upregulation was evident already before the maximum water temperature of $26^{\circ} \mathrm{C}$ was reached (T1), and it was maintained throughout the duration of the heat wave (T1 to T4). In comparison, for Ebeltoft plants we found the first significant upregulation of SOD Mn only when $26^{\circ} \mathrm{C}$ was reached (T2, Fig. 5e) persisting only until T3 (Fig. 5h).
Additionally, in the Gabicce Mare population, SOD Mn was the only gene to be significantly expressed during the heat wave (T1 to T4). The expression patterns in both high-latitude populations were more variable. In addition to SOD Mn, it included significant upregulation of APX in plants from Doverodde at T2 (Fig. 5f) and from Ebeltoft at T3 (Fig. 5h), and a significant downregulation of the gene coding for the chloroplast precursor protein of photosystem II (PS II) in the Ebeltoft plants at T3 (Fig. 5h). Once temperature was returned to the control levels (T5), all genes were down-regulated in the plants from Gabicce Mare, while plants from both high-latitude populations showed again a much more variable response, with some genes being upregulated while others downregulated (although up or down-regulations during this time point were not significant) (Fig. 5n,o). The populations also differed in the expression pattern found at T9, measured $9 \mathrm{~d}$ after the small and short second heat wave $\left(\leq 23^{\circ} \mathrm{C}\right.$ for $6 \mathrm{~h}$; caused by the failure in our cooling systems) that was experienced by all treatments. At T9 we found that most or all genes were upregulated in both the Gabicce Mare (5/6 genes) and Doverodde (6/6 genes) populations, significant though only for SOD Mn in the Gabicce Mare population (Fig. 5s) and for CAT in the Doverodde population (Fig. 5r). In contrary, the expression of genes in the Ebeltoft population was more variable, with half of the genes being upregulated and half were downregulated, although none of these was significant (Fig. 5q).

\section{DISCUSSION}

Exposure to the experimental heat wave caused reductions in both $Y_{0}$ and ETR $_{\max }$ in all 3 Zostera marina populations. In both central response variables, $Y_{0}$ and $\mathrm{ETR}_{\max }$, we found no Treatment $\times$ Population or Treatment $\times$ Geographic origin interactions, suggesting that an increase in heat waves associated with global warming could impair photosynthesis in both low- and high-latitude populations. Bergmann et al. (2010) have also recently shown that exposure to this heat wave caused reductions in fitness correlated traits (shoot densities) across both low- and high-latitude populations.

Compared to the photophysiology of both highlatitude populations, low-latitude plants revealed smaller reductions in $\alpha$ and $\mathrm{ETR}_{\text {max }}$ post treatment and a full recovery in both $Y_{0}$ and $\alpha$ values at the end of the experiment. These differences might be some evidence of long lasting photosynthetic damage in the high-latitude populations compared with the low-latitude population which might recover better from thermal stress in terms of photosynthetic performance. 


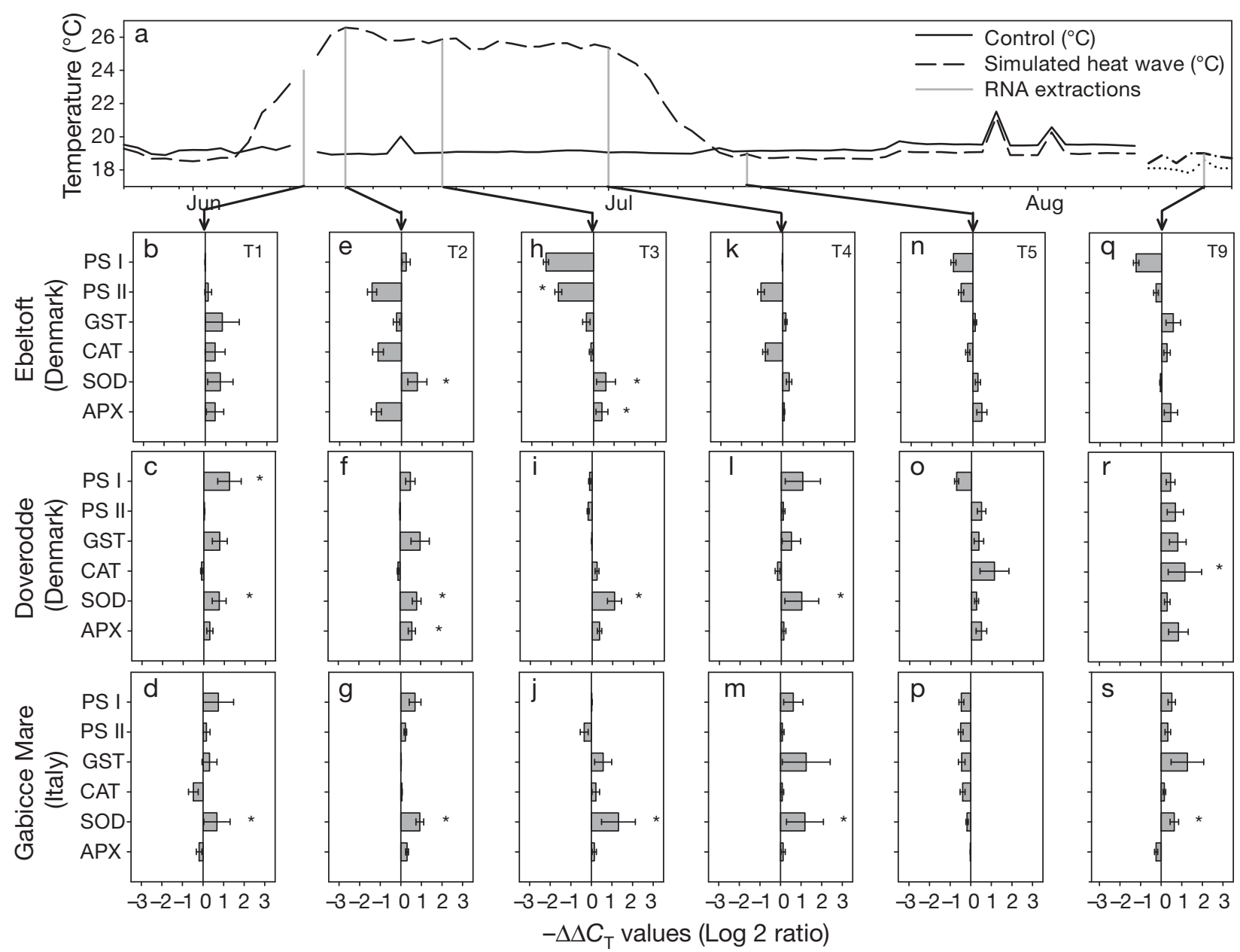

Fig. 5. Effects of a 3 wk simulated heat wave on gene expression (log 2 scale) of 3 populations of Zostera marina. (a) Daily mean water temperature $\left({ }^{\circ} \mathrm{C}\right.$ ) in control and simulated heat wave tanks. Mean $-\Delta \Delta C_{\mathrm{T}}$ values of 6 target genes (gene names abbreviated, for full name see Table 1) measured from 6 different RNA sampling time points for plants from Ebeltoft, Denmark (b,e,h,k,n and q), Doverodde, Denmark (c,f,i,l,o, and r) and Gabicce Mare, Italy $(\mathrm{d}, \mathrm{g}, \mathrm{j}, \mathrm{m}, \mathrm{p}$ and s). For each population and time point: means $\pm \mathrm{SE}, \mathrm{n}=5$. *: significant $(\mathrm{p}<0.05)$ expression levels compared to the control. See text for details

Why initial exposure to thermal stress actually increased $\alpha$ is currently unclear and contradicts older findings where this light-dependent part of the photosynthesis-irradiance $(P-E)$ curve was temperature independent (Jassby \& Platt 1976, Bulthuis 1987). This could be due to the slow rate of temperature increase and relatively long duration of the thermal stress in the current study, compared with relatively short term thermal shock experiments used by others (Zimmerman et al. 1989). Indeed, when Zostera marina was exposed to increasing water temperatures $\left(8\right.$ to $\left.30^{\circ} \mathrm{C}\right)$, but was acclimated to each temperature for some weeks, $\alpha$ increased with increasing water temperature (Evans et al. 1986).

The temporary increases in both $Y_{0}$ and ETR $_{\max }$, might be related to the changes in the carbon balance experienced by the plants during the heat wave. Increases in $P_{\max }$ (the maximum photosynthetic rate of the $P$ - $E$ curve, parallel to $\mathrm{ETR}_{\max }$ in this study) as a function of temperature are probably mediated by respiration rates, shown to increase with temperature (Masini \& Manning 1997, Greve et al. 2003). Since respiration rates in Zostera marina can increase faster with temperature than photosynthetic rates (Marsh et al. 1986, Zimmerman et al. 1989), plants exposed to high temperatures suffer a negative carbon balance. Thus, the initial increases in relative $Y_{0}$ shown in the present study and by Ralph et al. (1998), could be explained by the plants' need to maintain a positive carbon balance which would entail increases in photosynthetic efficiency and/or the rate of electrons transferred through the electron transport chain (i.e. entailing increases in ETR).

Along with the companion study by Bergmann et al. (2010), our work is unique in that we not only imposed a gradual and realistic increase in temperature over sev- 
eral days, but also measured the physiological responses over weeks and included a long recovery period.

By combining physiological measurements with qRT-PCR (e.g. Bergmann et al. 2010, this study), we can identify ecologically important genes underlying species interactions and physiological tolerances, advancing our mechanistic insights into how organisms respond to environmental stress. The fact that all 3 populations upregulated SOD Mn during the heat wave, suggests a central role for this gene in the thermal stress response. SOD catalyzes the conversion of 2 superoxide anions $\left(\mathrm{O}_{2}^{-}\right)$into hydrogen peroxide $\left(\mathrm{H}_{2} \mathrm{O}_{2}\right)$ and $\mathrm{O}_{2}$ and alleviates oxidative stress (Bowler et al. 1992). Higher availability of SOD during thermal stress increases the ROS-scavenging capacity (i.e. the ability to detoxify/neutralize reactive oxygen species) in the cells, allowing plants to retain high photosynthetic capacities (Gupta et al. 1993). While all populations expressed SOD Mn during the experimental heat wave, the Ebeltoft plants showed the slowest thermal stress response and lacked the ability to keep up the upregulation of this gene throughout the duration of the heat wave. The 3 populations also differed in the suite of genes expressed during the heat wave, with both high-latitude populations demonstrating a variable expression pattern, compared with the low-latitude population in which SOD Mn was the only gene to be differentially expressed. This difference might be indicative of a higher level of oxidative stress in the high-latitude populations during this period. Indeed, for both the high-latitude populations, the heat wave presents a higher level of stress compared with the low-latitude population. This is also true for salinity levels in the mesocosm that were higher than experienced in situ by both high-latitude populations, but particularly the Ebeltoft population, which might have added to the thermal stress. The gene expression pattern of the 3 populations also differed at T9, measured several days after the second heat wave. The significant upregulation of SOD Mn in plants from Gabicce Mare and of CAT for plants from Doverodde at T9 might have been caused by the second heat wave; however, it could also have been a late response to the first and prolonged heat wave. Since all plants, including controls, were exposed to the second temperature rise, we are unable to resolve this issue. Interestingly, however, the Ebeltoft plants did not significantly upregulate any antioxidant genes after this second heat wave. The fact that, in this study, thermal stress was not associated with a consistent upregulation of any other antioxidant gene besides SOD Mn could be due to superoxide dismutase being among the first antioxidants to be activated in the cells (Bowler et al. 1992). It is possible that exposing Zostera marina to more acute stress (e.g. higher temperatures) would have resulted in the consistent upregulation of more ROS-detoxifying genes (e.g. catalase, ascorbate peroxidase).

Our gene expression work concurs with the parallel findings of Bergmann et al. (2010): out of the 12 genes studied, 3 genes - heat shock proteins (hsp) hsp80 and hsp70, and the BIP gene (involved in leaf senescence) - were upregulated during several time points and explained most of the multivariate response to thermal stress. Similar to the lack of upregulation of antioxidant genes after the second short heat wave in the Ebeltoft plants found in our study, Bergmann et al. (2010) showed that following this second heat wave, Ebeltoft plants were the only population that failed to upregulate hsp80. Both studies point to the higher variability in gene expression (i.e. more genes up or down regulated) in Ebeltoft plants compared with the other 2 populations. While the work presented here pointed to some differences in the expression level, variability and timing between the 3 populations, neither study found a particular gene expression pattern affiliated with a thermal history. Indeed, both studies demonstrate different expression patterns for plants from Doverodde and Ebeltoft even though they come from similar thermal regimes, and similar expression patterns for plants from Gabicce Mare and Doverodde, although they come from very different thermal histories.

Predicted effects of climate change include changes in seagrass species distribution (Waycott et al. 2006, Björk et al. 2008). In northern Europe where seagrass diversity is very low, and where no other species could potentially replace Zostera marina, declines in this ecosystem engineering species would entail loss of the ecosystem associated with the meadows and enhancement of disturbances to nearby shores (Waycott et al. 2006). Although climate change is expected to force organisms to move north-south in order to stay in the same temperature (Loarie et al. 2009), it is assumed that low-latitude $Z$. marina populations growing in relatively warm waters, e.g. in the Adriatic Sea, will not be able to disperse around the Iberian Peninsula and reach high-latitudes. With $Z$. marina being successfully transplanted over large scales in many studies (reviewed by Fonseca et al. 1998, Busch et al. 2010), now might be the time to apply more drastic conservation measures to these important species. Although we did not show that $Z$. marina from the Adriatic Sea survives heat waves better than its northern conspecific over relatively short time scales, we cannot rule out that over an entire year cycle, or even over the lifetime of a clone, there are indeed differences among populations. Indeed, if $Z$. marina from low-latitude populations were shown to survive thermal events, targeted colonization of such resilient populations to high-latitude sites in northern Europe might be one of 
the tools that could help Z. marina prevail the climate projections (Hoegh-Guldberg et al. 2008). This would also enhance local meadow genotypic diversities, in itself shown to increase resilience to thermal stress (Reusch et al. 2005, Ehlers et al. 2008). Either way, it will be interesting to follow possible future changes in the Gabicce Mare population.

While the work presented here found some indications of a differential thermal stress response among the populations examined, the question of thermal adaptation of low-latitude populations of Zostera marina, including that in Gabicce Mare, remains to be further investigated. Compared with the relatively small number of genes studied here and in Bergmann et al. (2010), the recent application of full transcriptome sequencing, even in organisms for which there is still no genome (e.g. Meyer et al. 2009), such as $Z$. marina, offers great opportunities to scale up the number of genes we can now study. This could further elucidate possible genes and mechanisms involved in the adaptation to thermal stress.

Acknowledgements. We thank Nina Bergmann, Ilka Dankert and Barbara Hasert for laboratory assistance. Both Nina and Georg Plenge were a great asset to the Aquatron team. We thank Bettina Evers-Jansen (Danish Meteorological Institute), Marie-Louise Maarup (Agency for Spatial and Environmental Planning, Ministry of Environment, Denmark) and Stefano Serra (Agenzia Regionale per la Prevenzione e l Ambiente dell Emilia-Romagna, ARPA, Italy) for providing long term temperature data. We thank Sven Beer for advice with PAM fluorometry. This project was funded by the priority program AQUASHIFT of the DFG (to T.B.H.R.; RE 1108/9), and by the Minerva foundation (to G.W.).

\section{LITERATURE CITED}

Ackerly DD, Dudley SA, Sultan SE, Schmitt J and others (2000) The evolution of plant ecophysiological traits: recent advances and future directions. Bioscience 50: 979-995

Beer S, Björk M (2000) Measuring rates of photosynthesis of two tropical seagrasses by pulse amplitude modulated (PAM) fluorometry. Aquat Bot 66:69-76

Bergmann N, Winters G, Rauch G, Eizaguirre C and others (2010) Population-specificity of heat stress gene induction in northern and southern eelgrass Zostera marina populations under simulated global warming. Mol Ecol 19: 2870-2883

Björk M, Short F, Mcleod E, Beer S (2008) Managing seagrasses for resilience to climate change IUCN Resilience Science Group Working Paper Series-No 3. IUCN, Gland, p 56

Bowler C, Montagu MV, Inze D (1992) Superoxide dismutase and stress tolerance. Annu Rev Plant Physiol Plant Mol Biol 43:83-116

Bulthuis DA (1987) Effects of temperature on photosynthesis and growth of seagrasses. Aquat Bot 27:27-40

Busch KE, Golden RR, Parham TA, Karrh LP, Lewandowski MJ, Naylor MD (2010) Large-scale Zostera marina (eel- grass) restoration in Chesapeake Bay, Maryland, USA. Part I: a comparison of techniques and associated costs. Restor Ecol 18:490-500

> Campbell SJ, McKenzie LJ, Kerville SP (2006) Photosynthetic responses of seven tropical seagrasses to elevated seawater temperature. J Exp Mar Biol Ecol 330:455-468

den Hartog C (1970) The seagrasses of the world. Verhandlingen Koninglijk Nederlandse Akademie Wetenschapen Afdeling Natuurkunde II 59:1-275

Desalvo MK, Voolstra CR, Sunagawa S, Schwarz JA and others (2008) Differential gene expression during thermal stress and bleaching in the Caribbean coral Montastraea faveolata. Mol Ecol 17:3952-3971

> Desalvo MK, Sunagawa S, Fisher PL, Voolstra CR, IglesiasPrieto R, Medina M (2010) Coral host transcriptomic states are correlated with Symbiodinium genotypes. Mol Ecol 19:1174-1186

Dutta S, Mohanty S, Tripathy BC (2009) Role of temperature stress on chloroplast biogenesis and protein import in pea. Plant Physiol 150:1050-1061

Ehlers A, Worm B, Reusch TBH (2008) Importance of genetic diversity in eelgrass Zostera marina for its resilience to global warming. Mar Ecol Prog Ser 355:1-7

Eilers PHC, Peeters JCH (1988) A model for the relationship between light intensity and the rate of photosynthesis in phytoplankton. Ecol Modell 42:199-215

> Etterson JR, Shaw RG (2001) Constraint to adaptive evolution in response to global warming. Science 294:151-154

- Evans AS, Webb KL, Penhale PA (1986) Photosynthetic temperature acclimation in two coexisting seagrasses, Zostera marina L. and Ruppia maritima L. Aquat Bot 24:185-197

Fonseca M, Kenworthy WJ, Thayer GW (1998) Guidelines for the conservation and restoration of seagrasses in the United States and adjacent waters, NOAA'S coastal ocean program. Decision analysis series No. 12, Silver Spring, MD

Fowler J, Cohen L, Jarvis P (1998) Practical statistics for field biology. Wiley \& Sons, Chichester

> Greve TM, Borum J, Pedersen O (2003) Meristematic oxygen variability in eelgrass (Zostera marina). Limnol Oceanogr 48:210-216

Gupta AS, Heinen JL, Holaday AS, Burke JJ, Allen RD (1993) Increased resistance to oxidative stress in transgenic plants that overexpress chloroplastic $\mathrm{Cu} / \mathrm{Zn}$ superoxide dismutase. Proc Natl Acad Sci USA 90:1629-1633

Hall TA (1999) BioEdit: a user-friendly biological sequence alignment editor and analysis program for Windows 95/98/NT. Nucl Acids Symp Ser 41:95-98

Havaux M (1993) Characterization of thermal damage to the photosynthetic electron transport system in potato leaves. Plant Sci 94:19-33

Heid CA, Stevens J, Livak KJ, Williams PM (1996) Real time quantitative PCR. Genet Res 6:986-994

> Hoegh-Guldberg O, Hughes L, McIntyre S, Lindenmayer DB, Parmesan C, Possingham HP, Thomas CD (2008) Assisted colonization and rapid climate change. Science 321: 345-346

Jassby AD, Platt T (1976) Mathematical formulation of the relationship between photosynthesis and light for phytoplankton. Limnol Oceanogr 21:540-547

Jones CG, Lawton JH, Chachak M (1994) Organisms as ecosystem engineers. Oikos 69:373-386

> Jump AS, Penuelas J (2005) Running to stand still: adaptation and the response of plants to rapid climate change. Ecol Lett 8:1010-1020

Larcher W (1994) Photosynthesis as a tool for indicating temperature stress events. In: Schulze ED, Caldwell MM 
(eds) Ecophysiology of photosynthesis. Springer, Berlin, p 261-277

Livak KJ, Schmittgen TD (2001) Analysis of relative gene expression data using real-time quantitative PCR and the $2^{-\Delta \Delta \mathrm{Ct}}$ method. Methods 25:402-408

Loarie SR, Duffy PB, Hamilton H, Asner GP, Field CB, Ackerly DD (2009) The velocity of climate change. Nature 462: 1052-1055

Marsh JA, Dennison WC, Alberte RS (1986) Effects of temperature on photosynthesis and respiration in eelgrass (Zostera marina L.). J Exp Mar Biol Ecol 101:257-267

Masini RJ, Manning CR (1997) The photosynthetic responses to irradiance and temperature of four meadow-forming seagrasses. Aquat Bot 58:21-36

Massa S, Arnaud-Haond S, Pearson G, Serrão E (2008) Temperature tolerance and survival of intertidal populations of the seagrass Zostera noltii (Hornemann) in Southern Europe (Ria Formosa, Portugal). Hydrobiologia 619: 195-201

Meyer E, Aglyamova G, Wang S, Buchanan-Carter J and others (2009) Sequencing and de novo analysis of a coral larval transcriptome using 454 GSFlx. BMC Genomics 10:219

Millien V, Kathleen Lyons S, Olson L, Smith FA, Wilson AB, Yom-Tov Y (2006) Ecotypic variation in the context of global climate change: revisiting the rules. Ecol Lett 9:853-869

Moore KA, Short FT (2006) Zostera: biology, ecology, and management. In: Larkum AWD, Orth RJ, Duarte CM (eds) Seagrasses: biology, ecology and conservation. Springer, Dordrecht, p 361-386

Peat HJ, Fitter AH (1994) Comparative analyses of ecological characteristics of British angiosperms. Biol Rev Camb Philos Soc 69:95-115

Pfaffl MW, Horgan GW, Dempfle L (2002) Relative expression software tool (RESTC) for group-wise comparison and statistical analysis of relative expression results in realtime PCR. Nucleic Acids Res 30:e36

> Procaccini G, Olsen JL, Reusch TBH (2007) Contribution of genetics and genomics to seagrass biology and conservation. J Exp Mar Biol Ecol 350:234-259

Pulido C, Borum J (2010) Eelgrass (Zostera marina) tolerance to anoxia. J Exp Mar Biol Ecol 385:8-13

Ralph PJ, Gademann R (2005) Rapid light curves: a powerful tool to assess photosynthetic activity. Aquat Bot 82:222-237

Ralph PJ, Gademann R, Dennison WC (1998) In situ seagrass photosynthesis measured using a submersible, pulseamplitude modulated fluorometer. Mar Biol 132:367-373

Ransbotyn V, Reusch TBH (2006) Housekeeping gene selection for quantitative real-time PCR assays in the seagrass Zostera marina subjected to heat stress. Limnol Oceanogr

Editorial responsibility: William Kemp,

Cambridge, Maryland, USA
Methods 4:367-373

> Reusch TBH, Wood TE (2007) Molecular ecology of global change. Mol Ecol 16:3973-3992

Reusch TBH, Ehlers A, Haemmerli A, Worm B (2005) Ecosystem recovery after climatic extremes enhanced by genotypic diversity. Proc Natl Acad Sci USA 102:2826-2831

Reusch TBH, Veron A, Preuss C, Weiner J and others (2008) Comparative analysis of expressed sequence tag (EST) libraries in the seagrass Zostera marina subjected to temperature stress. Mar Biotechnol 10:297-309

> Rice KJ, Emery AC (2003) Managing microevolution: restoration in the face of global change. Front Ecol Environ 1: $469-478$

> Rozen S, Skaletsky H (2000) Primer3 on the WWW for general users and for biologist programmers. Methods Mol Biol 132:365-386

Saroussi S, Beer S (2007) Alpha and quantum yield of aquatic plants derived from PAM fluorometry: uses and misuses. Aquat Bot 86:89-92

Schär C, Jendritzky G (2004) Hot news from summer 2003. Nature 432:559-560

Schär C, Vidale PL, Lüthi D, Frei C, Häberli C, Liniger MA, Appenzeller C (2004) The role of increasing temperature variability in European summer heatwaves. Nature 427: 332-335

Sharkey TD (2005) Effects of moderate heat stress on photosynthesis: importance of thylakoid reactions, rubisco deactivation, reactive oxygen species, and thermotolerance provided by isoprene. Plant Cell Environ 28: 269-277

Sharon Y, Silva J, Santos R, Runcie JW, Chernihovsky M, Beer S (2009) Photosynthetic responses of Halophila stipulacea to a light gradient. II. Acclimations following transplantation. Aquat Biol 7:153-157

Waycott M, Collier C, McMahon K, Ralph P, McKenzie L, Udy J, Grech A (2006) Vulnerability of seagrasses in the Great Barrier Reef to climate change. In: Johnson JE, Marshall PA (eds) Climate change and the Great Barrier Reef. Great Barrier Reef Marine Park Authority and Australian Greenhouse Office, Townsville, p 44

Wissler L, Dattolo E, Moore AD, Reusch TBH and others (2009) Dr. Zompo: an online data repository for Zostera marina and Posidonia oceanica ESTs. Database 2009: bpa009

Wyllie-Echeverria S, Cox PA (1999) The seagrass (Zostera marina, Zosteraceae) industry of Nova Scotia (1907-1960). Econ Bot 53:419-426

> Zimmerman RC, Smith RD, Alberte RS (1989) Thermal acclimation and whole-plant carbon balance in Zostera marina L. (eelgrass). J Exp Mar Biol Ecol 130:93-109

Submitted: October 25, 2010; Accepted: May 16, 2011 Proofs received from author(s): July 27, 2011 